DOI: 10.12731/2227-930X-2017-2-48-55

\title{
WORKING MACHINE-HOUR COST COMPARISON OF MODERN ROAD COVERAGE PROCESSING MECHANIZATION
}

\section{Izmaylova D.K., Seliverstov N.D.}

In the article there are mentioned features of alternative mechanization machine-hour cost calculations. Also determined analytical dependencies of calculating the expenses of ownership and maintenance. Given a comparison of expense items of various options for the processing implementation. The analysis is based on the international organizing experience for these types of work.

Keywords: processing; road coverage; mechanization; machine-hour cost; cost of depreciation.

\section{Introduction}

Economic efficiency of the machines is determined by costs of purchase, maintenance, repairing and relocation. The amount of costs mainly depends on the type of machine, working conditions, length of the operation period as well as on the terms of insurance and taxation.

Total costs of ownership and maintenance of the machinery during its operation period can be calculated approximately [1]. Total costs of ownership and maintenance will be largely determined by sales/purchase price and the cost of maintenance in operation period. The sales/ purchase price is determined as the difference between the purchase price, which includes the delivery of the equipment to customer and the resale value of the machine. The resale value is determined by the chosen methods of depreciation in the accounting and taxation $[3,6]$.

\section{Cost determination by expenditure}

The cost of mechanization working machine-hour is determined by the equation: 


$$
C_{A M}=C_{M Y c o n s t}+C_{M U_{v a r}}+C_{\text {OIEP }}, \text { rub./h; }
$$

$C_{M Y c o n s t}-$ cost of ownership (constant), rub./h;

$C_{M U_{\text {var }}}-$ cost of maintenance (variable), rub./h;

$C_{\text {OIEP }}$ - hourly operator tariff rate, rub./h;

The cost of ownership is determined by the equation:

$$
C_{M Y c o n s t}=C_{A M}+C_{\text {ДOX }}+C_{H A J}+C_{C T P A X} \text {, rub./h; }
$$

$C_{A M}$ - depreciation value, rub./h;

$C_{\text {дох }}$ - the amount of income from ownership, rub./h;

$C_{H A J}-$ taxes, rub./h;

$C_{C T P A X}-$ insurance, rub./h;

Depreciation value is calculated on the basis of the equation:

$C_{\text {MAII }}$ - machinery price, rub.;

$$
C_{A M}=\frac{C_{M A \amalg I}-C_{I P O Д}}{T_{B Л} \cdot N_{M Y}}, \text { rub./h; }
$$

$C_{\text {ПРОД }}-$ cost of resale, rub.;

$T_{B J}$ - total estimated life of the machinery, year;

$N_{M Y}$ - number of machine-hours of work per year, hour/year.

In Fig. 1 there are given depreciation costs of alternative processing mechanization.

1) Purchase costs on machinery are determined considering the cost of resale, which depends on many factors: the age of the machine; the number of machine-hours to the time of resale or exchange; type of work and operating conditions; physical condition [5].

The amount of income from possession is determined by the equation:

$x$ - income rate, $\%$.

$$
C_{\text {सоX }}=\frac{\left[\frac{x}{100} \cdot \frac{C_{\text {MAUI }}+C_{\text {проО }}}{2}\right]}{N_{\text {MU }}}=\frac{x \cdot\left(C_{\text {MAIU }}+C_{\text {IтоI }}\right)}{200 \cdot N_{\text {MU }}}, \text { rub./h; }
$$

Cost of taxation and insurance:

$$
C_{H A J}=\frac{C_{H A I . C T}}{N_{M Y}} ; C_{C T P A X}=\frac{C_{C T P A X . C T}}{N_{M Y}},
$$

$C_{\text {НАЛ.СT }}$ - annual cost of taxation, rub./year;

$C_{C T P A X . C T}-$ annual cost of insurance, rub./year; 


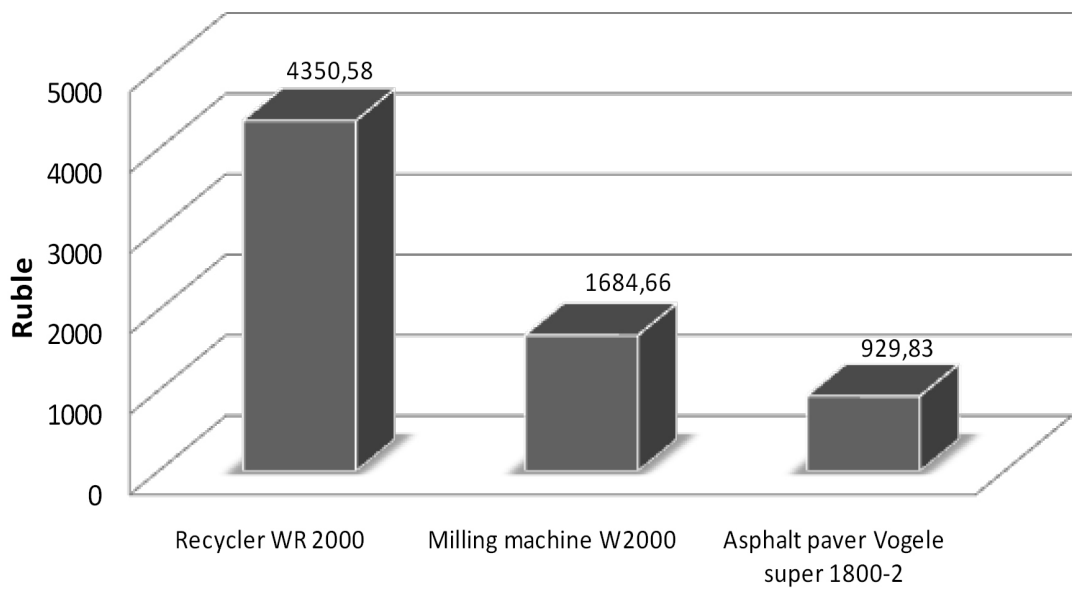

Fig. 1. Depreciation expenses of alternative processing mechanization machine-hour work

2) Information about maintenance costs, repairing and relocation in the market conditions is a trade secret. The amount of costs for maintenance also depends on the number of operating machine-hours and conditions of operating.

The content cost is determined by the equation:

$$
C_{M Ч \text { var }}=C_{\text {ТОП }}+C_{\text {СМАЗ }}+C_{\text {ДвИж }}+C_{P М} \text { rub./h; }
$$

$C_{\text {TOП }}-$ cost of fuel, rub./h;

$C_{C M A 3}-$ cost of lubricants, rub./h;

$C_{\text {движ }}-$ cost of the propulsor, rub./h;

$C_{P M}-$ cost of consumables (cutting element), rub./h;

Cost of fuel:

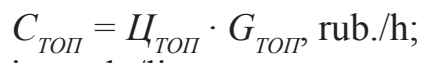

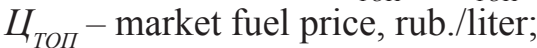

$G_{T O \Pi}-$ hourly fuel consumption, liter/hour;

Cost of lubricants:

$$
L_{C M A 3}=L_{C M A 3} \cdot G_{C M A 3}, \text { rub./h; }
$$

$L_{C M A 3}$ - market price of lubricants, rub./liter;

$G_{C M A 3}$ - hourly consumption of lubricants, liter/hour; 


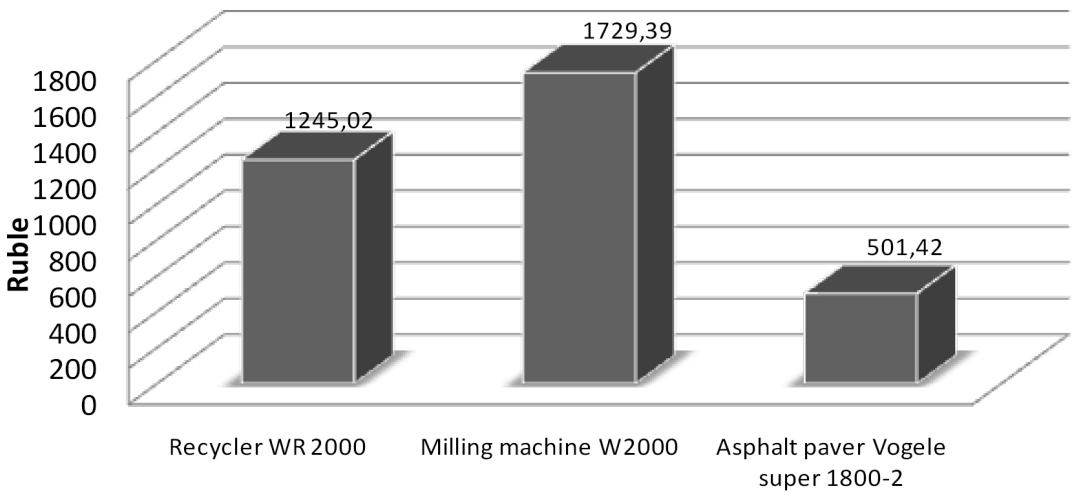

Fig. 2. Fuel and lubricants expenses of alternative processing mechanization machine-hour work

3) Taxation, equipment insurance, fuel and lubricants costs can change during operation process. If the duration period of the unit, maintenance and repair conditions, as well as insurance and taxation conditions change, the prime cost of the machine-hour operation adjusts.

Figures 2, 3 and 4 show the data of expense for fuel and lubricants, hydraulic fluid and maintenance and repair of alternative processing mechanization.

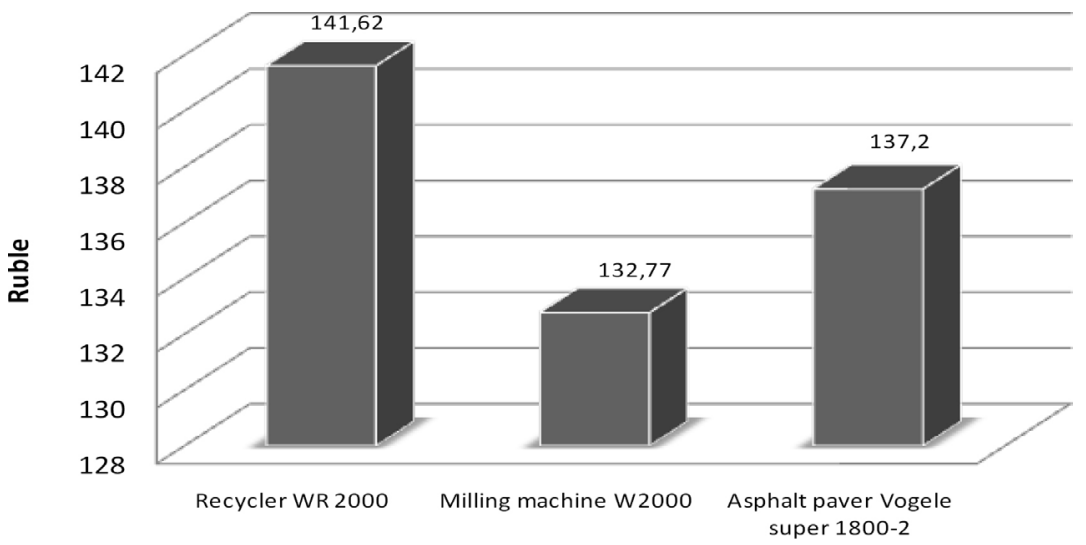

Fig. 3. Hydraulic fluid expenses of alternative processing mechanization machine-hour work 


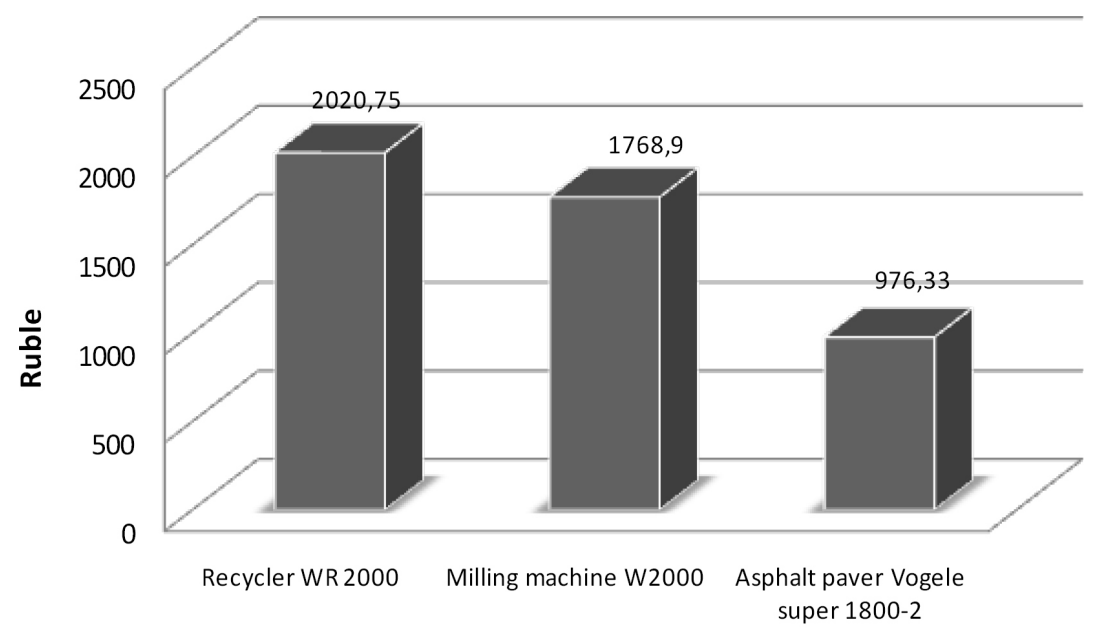

Fig. 4. Maintenance and repair expenses of alternative processing mechanization machine-hour work

The prime cost of the propulsor:

$$
C_{\text {движ }}=\frac{Ц_{д в и ж}}{T_{\text {движ }}}, \mathrm{rub} . / \mathrm{h} ;
$$

$Ц_{\text {движ }}$ - the cost of the propulsion unit, rub.;

$T_{\text {движ }}$ - total estimated service life of the kit, hour;

The cost price of the consumable material (cutting element) is determined by the equation:

$\bigsqcup_{1 P M}-$ cost of the cutting element, rub./pcs;

$$
C_{P M}=L_{1 P M} \cdot \frac{n_{B V}}{Q} \cdot \Pi_{\Phi}=Ц_{1 P M} \cdot \frac{n_{b Y}}{t_{L}}, \mathrm{rub} . / \mathrm{h} ;
$$

$\frac{n_{5 Y}}{O}-$ consumption of cutting elements, $\mathrm{pcs} / \mathrm{m}^{3}$

$\Pi_{\Phi}-$ milling productivity, $\mathrm{m}^{3} / \mathrm{h}$;

$t_{L}$-duration of the cycle (period) of milling, $\mathrm{h}$.

\section{Cost calculation of a machine-hour work}

Cost calculation of a machine-hour work of a recycler (processor), a road milling machine and an asphalt paver involves calculations of 
several types of costs. The expenses for the working machine-hour of mechanization are presented in Table 1.

Table 1.

Calculation of the road machinery machine-hour costs

\begin{tabular}{|l|c|c|c|}
\hline \multirow{2}{*}{ Expenditure } & \multicolumn{3}{|c|}{ Expenses of mechanization, rub/h } \\
\cline { 2 - 4 } & $\begin{array}{c}\text { Milling } \\
\text { machine } \\
\text { W2000 }\end{array}$ & $\begin{array}{c}\text { Asphalt paver } \\
\text { Vogele super } \\
1800-2\end{array}$ & $\begin{array}{c}\text { Recycler WR } \\
2000\end{array}$ \\
\hline Depreciation & 1684,66 & 2059,6 & 4350,58 \\
\hline $\begin{array}{l}\text { Costs of remuneration for drivers } \\
\text { and machine operators }\end{array}$ & 273,45 & 273,45 & 215,12 \\
\hline $\begin{array}{l}\text { Costs of fuel and lubricants for } \\
\text { the machines and mechanisms } * *\end{array}$ & 1729,39 & 501,42 & 1245,02 \\
\hline Costs of hydraulic fluid & 132,77 & 137,2 & 141,62 \\
\hline Tire costs & - & - & 84,74 \\
\hline $\begin{array}{l}\text { Costs of relocating the machinery } \\
\text { on a trailer }\end{array}$ & 78,41 & 78,41 & $78,41 / 866,58 *$ \\
\hline Maintenance and repair costs & 1768,9 & 1213,2 & 2020,75 \\
\hline Total $C_{M Y}$ & $5666 \mathrm{rub} / \mathrm{h}$ & $4264 \mathrm{rub} / \mathrm{h}$ & $8923 \mathrm{rub} / \mathrm{h}$ \\
\hline
\end{tabular}

*-self-relocation

\section{Conclusion}

The analysis of organizational and economic activities at all stages of the production process allows to increase competitiveness of products. Cost of road construction works reduction is the main clause of competitiveness, efficiency increase and profitability [2, 7].Unit cost of coating layers repairing is determined primarily by the cost of asphalt mix. The dynamics of the direct total cost of repairs is determined by the degree of re-use and workload.

Depreciation charges form basing on the price of the machine and annual operating mode, which determine the monthly depreciation rate, as well as depreciation of a one machine-hour. The costs of remuneration for drivers and machine operators are calculated basing on the hourly rate of the employee, including premiums and insurance premiums. The costs of fuel and lubricants 
for the machinery and mechanisms are determined by the cost of materials and fuel consumption rates in liters per hour of work. The costs of the hydraulic fluid depend on the capacity of the hydraulic system, density of the hydraulic fluid, frequency of the full replacement (times per year), price of fluid and consumption per one machine-hour. Calculation costs of stabilizer tires are based on the average annual mileage, tire price, tire delivery cost factor and restorating and repairing costs of tires. The costs of relocating on a trailer are determined depending on fuel consumption per 100 $\mathrm{km}$ and fuel prices in the region. The relocation of stabilizers is possible self-propelling. The costs for maintenance and repair are established on the basis of estimated replacement cost and working time balance.

\section{References}

1. Izmaylova D.K., Dreytsen M.A. Improving indicators of motor complex organization on the basis of modern concepts of functioning // Economics and society 2015. №2-2 (15), pp. 686-688.

2. Izmaylova D.K., Seliverstov N.D. Evaluation of the restoring costs of road surface based on non-waste technology work // Repair, restoration, modernization. 2017. № 3, pp. 38-44.

3. Izmaylova D.K., Seliverstov N.D. Economics of non-waste technologies in Russia // Repair, restoration, modernization. 2016. № 12, pp. 37-40.

4. Kustarev G.V., Seliverstov N.D. Ways of development of recycling pavements technologies in Russia // Building equipment. 2015. № 12 (858), pp. 4-8.

5. Caterpillar Performance Handbook. Technical and operational characteristics of machines of the Caterpillar company: Handbook. USA, Peoria, Illinois: Caterpillar Inc., 2007. 1308 p.

6. Izmaylova D.K., Seliverstov N.D. Economy of a Non-waste Road Repairing and Covering Technology in Different Countries // International Journal of Advanced Studies. 2016. Vol. 6. № 3, pp. 3-6. DOI: 10.12731/2227-930X-2016-3-1. 
7. Izmaylova D.K., Seliverstov N.D. Economic Indicators of Road Surfaces Reconstructions in the World Using Non-waste Technology // International Journal of Advanced Studies. 2016. Vol. 6. № 3, pp. 7-11. DOI: 10.12731/2227-930X-2016-3-2.

\section{DATA ABOUT THE AUTHORS}

Izmaylova Dilyara Kyazymovna, Ph. D., Ass. Professor Department Economics of Road Transport

State Technical University - MADI

64, Leningradsky prospekt, Moscow, 125319, Russian Federation izmailovadk@list.ru

Seliverstov Nikolay Dmitrievich, Ph. D., Ass. Professor Department Road-building machinery

State Technical University - MADI

64, Leningradsky prospekt, Moscow, 125319, Russian Federation seliverstov_nd@inbox.ru 